Neuro Images
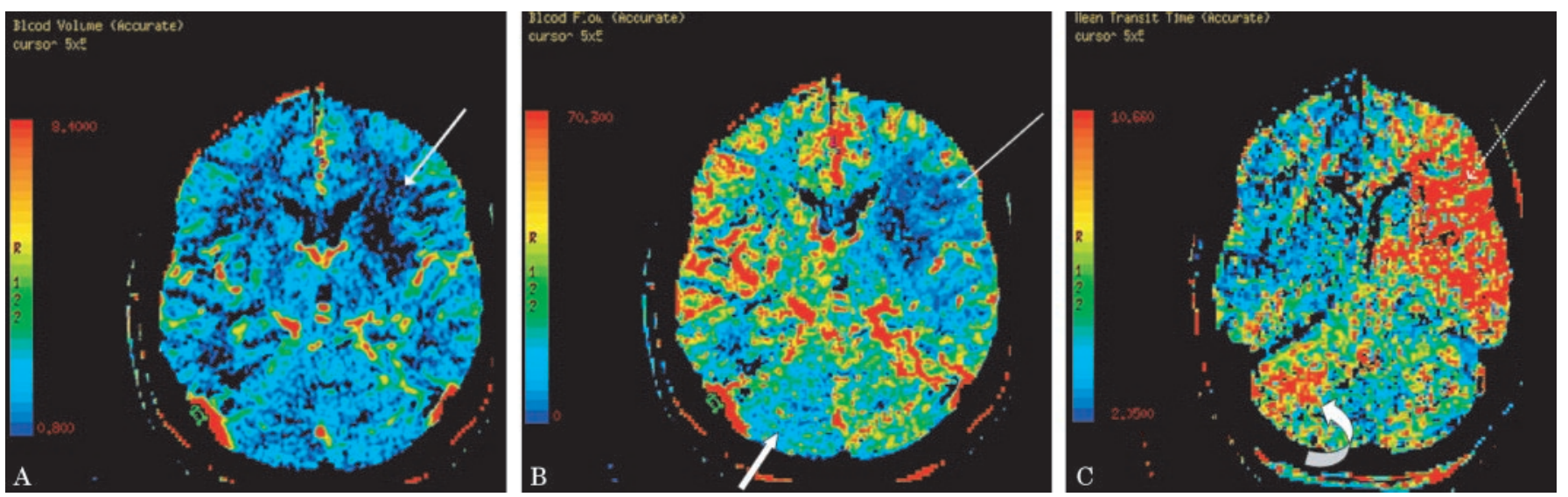

Figure. Cerebral blood volume is decreased in the left basal ganglia (white arrow) suggestive of infarcted tissue (A). There is a larger area of decreased cerebral blood flow (CBF) (white arrow) and increased mean transit time (MTT) (dotted arrow) suggestive of penumbra (B, C). The contralateral right cerebellar hemisphere shows an area of decreased CBF (broad arrow) and increased MTT (curved arrow) reflecting crossed cerebellar diaschisis $(B, C)$.

\section{Crossed cerebellar diaschisis in stroke}

Ashok Srinivasan, MD, William Miller, MD, Peter Stys, MD, and Mayank Goyal, MD, Ottawa, Canada

A 77-year-old woman presented within 90 minutes of onset of right hemiplegia and aphasia. The plain CT head scan was normal. CT angiogram revealed left internal carotid artery occlusion with thrombus in M1 segment of the left middle cerebral artery (MCA). CT perfusion revealed decreased cerebral blood flow, increased mean transit time, and normal cerebral blood volume in the right cerebellar hemisphere (contralateral to the penumbra in

Address correspondence and reprint requests to Dr. Mayank Goyal, Department of Diagnostic Imaging, The Ottawa Hospital, Civic Campus, Ottawa, ON K1Y 4E9, Canada; e-mail: mgoyal@ottawahospital.on.ca the left MCA territory) representing crossed cerebellar diaschisis (CCD) (figure).

CCD may be due to interruption of afferent corticopontocerebellar pathways and results in decreased blood flow and metabolism in the cerebellar hemisphere contralateral to a supratentorial lesion. ${ }^{1}$ The temporal changes and clinical significance of CCD in stroke are unclear despite a number of reports. Some authors consider acute stage CCD to be a significant predictor of stroke outcome, its absence being associated with favorable results. ${ }^{2}$

1. Baron JC, Bousser MG, Comar D, et al. Crossed cerebellar diaschisis in human supratentorial brain infarction. Trans Am Neurol Assoc 1980; 105:459-461.

2. Infeld B, Davis SM, Lichtenstein M, Mitchell PJ, Hopper JL. Crossed cerebellar diaschisis and brain recovery after stroke. Stroke 1995;26:90-95. 


\title{
Neurology
}

\author{
Crossed cerebellar diaschisis in stroke \\ Ashok Srinivasan, William Miller, Peter Stys, et al. \\ Neurology 2004;62;2130 \\ DOI 10.1212/01.WNL.0000123088.81455.F2
}

\section{This information is current as of June 7, 2004}

\section{Updated Information \& Services}

\section{References}

Citations

Subspecialty Collections

Permissions \& Licensing

Reprints including high resolution figures, can be found at: http://n.neurology.org/content/62/11/2130.full

This article cites 2 articles, 1 of which you can access for free at: http://n.neurology.org/content/62/11/2130.full\#ref-list-1

This article has been cited by 1 HighWire-hosted articles: http://n.neurology.org/content/62/11/2130.full\#\#otherarticles

This article, along with others on similar topics, appears in the following collection(s):

\section{Cerebellum}

http://n.neurology.org/cgi/collection/cerebellum

\section{CT}

http://n.neurology.org/cgi/collection/ct

Nerve tumor

http://n.neurology.org/cgi/collection/nerve_tumor

Information about reproducing this article in parts (figures,tables) or in its entirety can be found online at:

http://www.neurology.org/about/about_the_journal\#permissions

Information about ordering reprints can be found online: http://n.neurology.org/subscribers/advertise

Neurology ${ }^{\circledR}$ is the official journal of the American Academy of Neurology. Published continuously since 1951, it is now a weekly with 48 issues per year. Copyright . All rights reserved. Print ISSN: 0028-3878. Online ISSN: 1526-632X.

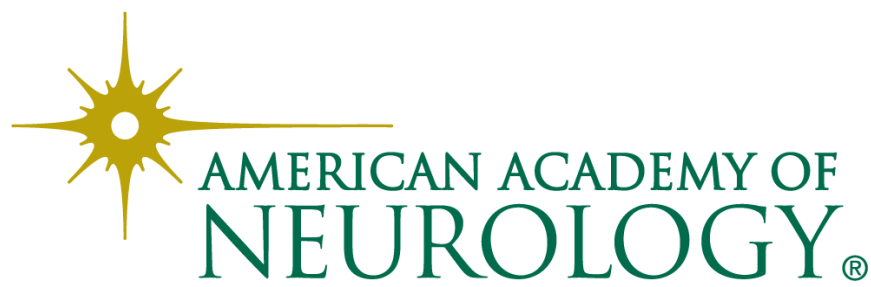

